\title{
The performance of secrecy: Domesticity and privacy in public spaces
}

\section{Citation}

Herzfeld, Michael. 2009. "The Performance of Secrecy: Domesticity and Privacy in Public Spaces." Semiotica 2009 (175) (January). doi:10.1515/semi.2009.044.

\section{Published Version}

doi:10.1515/semi.2009.044

\section{Permanent link}

http://nrs.harvard.edu/urn-3:HUL.InstRepos:34353683

\section{Terms of Use}

This article was downloaded from Harvard University's DASH repository, and is made available under the terms and conditions applicable to Other Posted Material, as set forth at http:// nrs.harvard.edu/urn-3:HUL.InstRepos:dash.current.terms-of-use\#LAA

\section{Share Your Story}

The Harvard community has made this article openly available.

Please share how this access benefits you. Submit a story.

Accessibility 


\title{
The performance of secrecy: Domesticity and privacy in public spaces
}

\author{
MICHAEL HERZFELD
}

\section{Abstract}

Secrecy, paradoxically, is a social fact; as such, it must be performed in order to be realized. This article is a programmatic attempt to explore the semiotics of secrecy as revealed through the interaction of architectonics, spatiality, and social interaction. Gestural secretiveness reproduces socially sanctioned patterns of concealment also embodied in the built environment; these social dimensions also inform local interpretations of legal devices designed to guarantee privacy. On the international stage, moreover, they are transformed into devices for the concealment of potential national embarrassments. As the author demonstrates using materials from Greece, Italy, and Thailand, the practical effects of secrecy - a more flexible construct than the dichotomy of public and private - are revealingly inscribed, at various concentric levels of social identification, on the material landscape of inhabited space, and represent a necessary dimension of adapting urban structures to a human scale.

Keywords: secrecy; spatiality; cultural intimacy; gesture; architectonics; social interaction.

In this exploratory essay, I put forward an attempt to bring together the study of architectonic space, the problem of secrecy and privacy in social relations, and the problem of social knowledge that can be "encrypted" (only readable by intimates already sworn to silence) only by dint of being "encoded" (rendered in a form hypothetically accessible to others). In this attempt, I am guided by two key insights that have arisen over many years of ethnographic field research: first, that secrecy must itself be performed in a public fashion in order to be understood to exist; and second, that this paradox is often deeply embedded in architecture of even the most public variety, and is certainly announced by domestic architecture. 
To understand this point about the built environment, it is important to appreciate the fact that it is not only individual people who have secrets. Kin groups, and even entire cultural entities and nation-states have proved assiduous in guarding their embarrassments from the prying eyes of outsiders. Clothing tells us a great deal about people (not all of it necessarily true); similarly, architecture is the clothing of the body politic, and displays a comparable interweaving of revelation, deception, and concealment.

A further observation that will help us through this brief discussion is that much of the language of anthropological theory is architectonic in implication (if not perhaps always in derivation). The most obvious term here is "structure," denoting a concept that reigned supreme in the discipline until Enlightenment ideals of perfect form began to contend more seriously with "messy" questions of human agency, indeterminacy, and unpredictability. Under the new conditions, structure has not disappeared. It has simply, but importantly, taken its place as the dialectical counterpart of agency; neither is conceivable in the absence of the other (Giddens 1984). This comprehensive realization reproduces in a more general form the early insights of writers like Simmel (1964), for whom secrecy was a social fact; the effort involved not only in maintaining a secret, but also in making sure that one's ability to do so is appreciated, cannot not exist in a vacuum, which is what lends secrecy its besetting instability and thereby invests it with both the high social value and the necessary indeterminacy associated with risk. Secrecy is always somewhat like gambling (see Malaby 2003); inasmuch as its performance is both its enabling condition and the source of its destruction, it is clearly a form of social agency. Moreover, it is an active form of self-protection, one that depends upon and utilizes the structural characteristics that make it possible to render secrecy palpable.

The relationship between individual and society is complex, and I do not intend to explore such well-traveled terrain here. I do wish to emphasize, however, that a perniciously evolutionist assumption about the nature of private space still persists even among writers who have come to recognize the importance of resisting the Scylla of methodological individualism and the Charybdis of sociocentrism alike. This assumption holds that the idea of privacy is an entirely modern notion. It is a prejudice that has been reinforced by numerous tales of anthropologists who have found it impossible to work alone, with the peace and quiet that their own notions of solitary intellectual contemplation seemed to demand. Chagnon's (1983: 15) imperial view of the matter, while perhaps depressingly appealing to anyone actually dealing with the social pressures of fieldwork, overlooks the fact that fieldwork itself is an invasion 
of privacy: "Privacy is one of our culture's most satisfying achievements, one you never think about until you suddenly have none. It is like not appreciating how good your left thumb feels until someone hits it with a hammer." In addition to the familiar self-reification implied by the notion of "our culture's achievements," the heroic allegory of fieldwork has a long genealogy in anthropological writing (e.g., Barley 1983; EvansPritchard 1940). ${ }^{1}$ The subject need not be a colonial possession or Third World state in order to generate such reactions; I have often heard casual comments to much the same effect from the mouths of anthropologists working in Mediterranean Europe. ${ }^{2}$ Against such stereotypes, however, we can again set a few exemplary refusals, such as Belmonte's (1979: 80) confident assertion: "Family life was private life in Naples, and family privacy was closely guarded and maintained." Friedl (1962: 14), writing of a Greek rural community, similarly speaks of "private family business." Difference lies, not in the presence or absence of privacy, but in the social pattern of its organization; and that difference may inform the management of privacy in even the most self-consciously modernist setting.

\section{Linguistic determinism and the problem of privacy}

The common assumption that privacy does not exist in rural cultures, or in cultures outside the strongholds of colonial rule, is reinforced by a persistent strain of linguistic determinism. In a curious inversion of SapirWhorf logic, it is assumed that, if a name does not exist for something, that something simply does not exist at all. Such nominalism is semiotically and logically as silly a piece of reductionism as the equally common and perhaps more familiar rejection of social phenomena that cannot be enumerated on the equally specious grounds that such data are irrelevant to a truly scientific study of society.

I have often heard it remarked about Mediterranean cultures in general, and about Greece in particular, that the word "privacy" has no exact local linguistic equivalent. This apparent fact — which might instead be regarded as an accident of translation - is often taken, at least implicitly, to mean that there is "no such thing" as privacy in these cultures. As a technical term associated with stereotypically "northern" value systems, to be sure, privacy is ideologically marked as standing in opposition to the sociality that southern Europeans no less stereotypically associate with themselves. It is especially seen as a civic value originating with concepts of property ownership and what the historian C. B. Macpherson 
(1962) saw as the concomitant ideology of "possessive individualism" a concept that, because it lies at the very heart of European and other nationalisms (see Handler 1985), should interest us very much indeed as a key link between privacy and national identity.

In Italy, the word "privacy" in its English form (la privacy) has an increasingly important legal status. It is associated there with an ongoing struggle over the status of individual rights in the face of increasing public surveillance; there is a committee to safeguard the public right to privacy, and its president rules on such questions as whether a taxi company may retain passenger information after the completion of the journey and transaction (it may not). Because surveillance itself has become an object of heated public debate, especially in the present era of paranoia about terrorism at home and abroad, the reification of the concept of privacy serves as a diagnostic of the shifting lines between domestic intimacy and public accountability; the goal of "audit culture" (Strathern 2000) can be seen, in these terms, as that of protecting the public realm from a converse invasion of privacy - of claims, in other words, that challenge the rights of the collective person that is the nation-state.

The concern with privacy varies from person to person, but it can be a highly effective way of beating off unwanted intrusions, including those of officialdom. Yet what seems to have changed, in Italy perhaps more dramatically than anywhere else with which I am familiar, is the degree to which a fiction of privacy allows for a very public sharing of secrets. One only need listen to the high-powered wheeling and dealing of brash young businesspeople using their cell phones on an airplane just before the doors close to realize that the apotheosis of private business - "privatization" - has enabled, perhaps even necessitated, a concomitant "publication" (I use this word advisedly in the present context) of ideal-typical forms of secrecy, confidentiality, and, indeed, privacy. Academics familiar with the peer review system will immediately recognize the phenomenon: the anonymity of authors and reviewers creates a civic fiction (since the chances are high that the identities of each side is known or at least accessible to the other), one that is designed to avert unseemly conflict while permitting the free expression of critical disagreement.

Thus, actions that used to be considered highly private - such as telephone conversations and amorous embraces - are now extremely visible and audible in those spaces hitherto regarded as reserved for public decorum. I have frequently encountered the phenomenon while filming in Rome, for example, where young people would cross the line of vision between my camera and my subject while chattering loudly on their cellular phones. There is no way they could not have been aware of my presence or the nature of my actions, and, in these days of enhanced media visibil- 
ity, there was every chance that their conversations might end up as part of a documentary. ${ }^{3}$ Yet the conversation, no doubt replete with highly personal references, appears here, not as a text to be kept confidential, but instead as a type of action that proclaims a right to privacy for all to see and, especially, to hear. Without access to the personal coordinates on which the speaker relies, no casual listener could really identify the content of the conversation. And so this very public demonstration of privacy affords the speaker a double right: to conduct a conversation without fear of being disturbed or deliberately decoded, but also to impose that conversation on a public sound-space in which, a few years ago, such actions would have been considered both rude and ingenuous.

In the European Mediterranean, cell phone use rapidly soared in part because of the extraordinary length of time - in Greece sometimes as much as seven years or longer - it took to get a land line. A more American reaction, by the few curmudgeonly enough to growl at (or at least about) the heedless majority, is to complain about "invasions of public space." But in Italy and Greece, where loud and highly dramatic arguments are often more about demonstrating autonomy and masculinity than they are about keeping secrets (at which people in both countries also excel), the cell phone is clearly not at all an instrument of privacy. On the contrary, it is an amplifier for self-promotion - as well, quite clearly, as a convenience in crowded cities with frenetic lifestyles.

This phenomenon must be read in parallel with the increasing tendency to privatize the physical as well as the auditory spaces of the urban landscape. In Italy, especially, the issue of the "occupation of public space" (occupazione del suolo pubblico) (see, e.g., Cellamare 2006) has come under intense scrutiny, as the "rights" of bar and restaurant owners to spread their tables (tavolini, significantly a diminutive form of the usual word for "tables") across public squares and sidewalks vie with the "public right" to a shared common space. Tourists who enjoy the amenities of such tables assume that this is a traditional Italian lifestyle - an assumption that encapsulates the unspoken assumption that social life in Italy is lived out in the open and that, indeed, there is no such thing as privacy. The entrepreneurs who profit from that assumption and trade on a vague sense of traditionalism have turned privacy into a public thing.

Before we proceed any further, it is important to examine the assumption that privacy is not a part of the traditional culture of southern European (or virtually any non-European) societies. Indeed, southern Europe, arena for the long battle in anthropology over the existence of values of "honor and shame," is the ideal place to examine such assumptions, since it is clear that - whatever the position one takes on the honor-and-shame debate itself - the terms that are so glossed are very much about what 
can be revealed to others - in other words, what we would ordinarily, at home, recognize as "the right to privacy."

I do not wish to rehearse that old debate here. There is no doubt that the societies that surround the Mediterranean sea exhibit a great concern with highly gendered - but also performatively negotiable (Cowan 1990) - models of what it is appropriate for others to know. Certainly, too, the terminology glossed as "shame" has more explicitly sexual implications, or so it would appear, than the more neutral-sounding English term "privacy," although the rights of "consenting adults in private" would appear to blur even this relatively innocuous-seeming distinction. Giddens' (1991) attempt to define modernity - a temporal substitute for "the West"? - in terms of a more individualistic sense of intimacy simply reproduces the same cultural hierarchy, with more than a slight undertow of the Victorian evolutionism that still persists in such formulations; he writes with a dismissive sweep of the "lack of privacy, characteristic of most circumstances of life in pre-modern Europe and in many nonmodern cultures generally" (1991: 94). Even the realization that shame is a social rather than an individual concern, a point that emerged early in the debates about Mediterranean cultures, does not contradict the equally social character of privacy; the contrast is a false and misleading one.

\section{Performances, privacy, and privilege}

Let me illustrate with an example drawn from my fieldwork in Italy. Once, when I was filming an open-air town meeting with people all of whom had previously expressed their willingness to let me film such events, I had inadvertently not obtained the agreement of one person who arrived late and whom I did not recognize at first as an individual who particularly disliked being caught on camera. The latecomer, instead of objecting immediately after arriving, remained near the center of the action for the rest of the meeting and then walked up to me toward the end of the meeting (after I had been filming for a considerable length of time) and, in a very audibly confrontational tone, declared, "I take my privacy very seriously (tengo molto alla mia privacy). ${ }^{4}$ At first, I was puzzled: why let me go on filming so long if the objections were really about privacy? I certainly am not questioning the person's sincerity or sense of principle; these issues are hardly germane here. Aside from what an alleged attempt to gesture me away, however, the protracted delay before voicing the objection suggests that the concern with la privacy had significant micro-political import. The entire performance was not only a public declaration; it was about the nature of public debate. It also shows, 
as other events have also demonstrated to me, that one can "discover" that one's privacy has been invaded after the fact - after viewing a photograph or film that was taken in good faith, for example, as a way of creating individual autonomy out of a collective situation.

The challenge to my research - which I subjectively experienced as an invasion of my own privacy and professional autonomy - was also a product of a rather particular moment in the history of Italian civic values. According to the universalist pretensions of the civic ethic, if everyone follows the same rules everything should be transparent. And if the purposes and goals of the meeting were truly transparent, there should have been nothing "interesting" about it. One might wish to argue that if all were transparent there should have been nothing to fear; but clearly transparency, which was all the rage in the political discourse of the time, is anything but transparent in its intentions and pragmatic consequences. "Privacy," too, was a political hot-button issue; privacy, too, was not necessarily always what it claimed to be. These paradoxes had their everyday social counterparts: just as public asseverations of fidelity to democratic rights often served to undermine the very civic values they purported to enshrine, so too demands for privacy can sometimes mask attempts to render a personal stance dramatically public. That, I suggest, is what happened here.

The space of the confrontation was a very public one: we were gathered, seated and standing in a group of perhaps fifty people, on a street that was actually a steep flight of steps - not, perhaps, the theatrical arena that seems to underlie the design of so many Italian piazze but a comparable if smaller stage that sported extensive evidence of private dwelling spaces all around it. The vocal objection, then, was a public demonstration, not of secrecy, but of a claim to be a very private person - to be a civic person. Civility (to say nothing of professional ethics) demanded that I offer to make amends, which I did; but standards of civility also exposed my critic to criticism for excessive (and obsessive) self-absorption and unfriendly behavior.

The incident illustrates some useful architectonic consequences of a distinction I increasingly find useful, between the civic and the civil. Civility is all about good manners and getting along, but it says nothing about intentions, legality, or morality. The civic sphere, on the other hand, is the space - so often misnamed "civil society" — in which equitable access to resources is negotiated and planned. The two often overlap, but in cities like Rome and Athens, where violations of zoning and historic conservation laws are an expression of social autonomy (see Caftanzoglou 2001; Faubion 1993; Herzfeld 2007), they often seem radically divergent. 
Standing on the steps of a civic meeting and invoking a civic principle (privacy) was clearly an act that both claimed and threatened norms of civility. The language used also claimed a form of transcendence - that is, it announced a principle that was not the product of local social norms but had more to do with some notion of "universal rights." The disintegration of socially diverse but intimate local societies in the centers of big Italian cities and the arrival of wealthy new residents with few neighborhood interests and many external activities means that la privacy, which for them may be a necessity, now becomes a social norm worthy of public emulation by those with an interest in social climbing. And this is an activity that can only be done - because such is the requirement of performativity — in public.

\section{Making secrecy visible: Cretan performances}

I now turn to a very different example, albeit one with strikingly - and interestingly - similar implications. The scene is the mountain village where I conducted fieldwork on a dramatically "traditional" Cretan community replete with vendettas, animal theft, and swaggering masculinity and severe attitudes concerning sexual morality. With the warm approval of the officers of the village's cultural association, my wife was photographing a collective attempt to clean away the garbage that had accumulated in a dry riverbed near the center of the village. The association officers were particularly pleased, it seemed, by our observation that this was a relatively rare and praiseworthy attempt to clean up a deeply ravaged local environment. Suddenly, however, one man erupted from the cleaning team and angrily threatened to smash my wife's camera if she continued. His anger, it seems, stemmed from the fact that the cleaners were by this time all physically filthy. In a society in which appearances become the basis of moral judgment, this was deeply demeaning to him. Eventually the conflict was resolved, and the offended party became my sindeknos - a ritual kinsman with whom the relationship was cemented by the conduct of a reconciliation ceremony (sasmos, literally "straightening out").

The entire confrontation was dramatically public. Indeed, in order to resolve the situation, I was forced to declare, loudly and in a very public space, that we had been cruelly threatened; those who intervened were in fact the offended party's patrilineal nake relatives (this is a clan-based society). Their collective reputation was now at stake; they had a strong collective interest in achieving a reconciliation that would deflect any further embarrassment. Here we are looking at a community in which the 
conventional values usually glossed as honor and shame were very much part of daily life, and it would be easy - and not entirely inaccurate - to explain the entire incident in terms of the "shame" of being photographed with dirty work clothes. Yet the similarity between these two incidents suggests something beyond either shared Mediterranean values of a Cretan village and a major Italian city or the usual occupational hazards associated with anthropological fieldwork. They also both suggest that, while people doubtless care a great deal about their privacy, that concern is also very much a matter of laying public claim to respectability. So the "transition" (if it is one) to modernity is not only a matter of shifting the emphasis of motivation "duty to desire," as Collier (1997) has persuasively argued; it is also, and concomitantly, a matter of demanding "respect" in terms of a more generic, bourgeois concern with the sole property capable of guaranteeing it - that is, "respectability." That modernity ideologically encourages people to give priority to desire over duty may, as Collier correctly argues, be true for particular places and cultures; and this is in part the result of the emergence of a relatively privileged and comfortable middle class. The resulting emphasis on the individual self, however, is not a rejection of the social, as neoliberals and neoconservatives from Margaret Thatcher on would have it. It is a profoundly social and ideological change, and its reception has varied enormously by generation, cultural and especially religious background, and economic conditions.

This shift to a more abstract sense of privacy - from socially embedded respect to formal norms of respectability - has important consequences for our consideration of the use of public space and for the means of closing off some spaces to outsiders. At the most inclusive level, it implies a sense of cultural hierarchy, in which the stereotypically "northern, "rational," and "civic" concern with privacy confers cultural superiority. For the Cretan man with his dirty clothes, this was simply a matter of the same kind of contempt for manual labor that we also see, for example, in working class Greeks' former habit of growing one extremely long fingernail in order to demonstrate their emancipation from that humiliating condition.

But let us return for a moment to the Italian example. Italy has, as I have already mentioned, been host to a very lively public discussion of the right to privacy. The offended party's loud insistence that there was in any case nothing special about the meeting I was recording, so that my entire effort was a pointless waste of time, was not so much a gratuitous insult as a further attempt to establish social advantage against an intruder and an outsider. It was a claim that the meeting was a normal part of civilized behavior and, as such, did not even deserve the attention 
of an anthropologist - often assumed to be a scholar of the exotic and the primitive. The fact that other local people then speculated long and delightedly about this person's motives in making such a fuss showed that the attempt to establish personal autonomy had substantially backfired; the speculations were unflattering, and very specifically revolved around the possibility that this person might have been afraid of a spouse's disapproval - there are still, apparently, some who think that such participation is neither respectable nor socially safe. The point is not that such allegations were necessarily justified, but that they were no less salient than the kind of backbiting that one might hear in a remote rural village. The one difference is that idioms of respectability and civic engagement had come to serve as the markers of status - of civiltà, a value that has a high valence even in the countryside (Silverman 1975; cf. Friedl 1964 for a comparable insight into Greek values).

In both cases, the event shaped the space: an arena was created for a public discussion on the steps of a public street in the Italian town, while a dramatic confrontation beside the bridge overlooking the dry riverbed in the Cretan village gave way to the more enclosed performance of reconciliation that occurred at the end of the same day in a "neutral" coffeehouse (see Herzfeld 1985: 285, n. 14). Both incidents, moreover, reveal four salient levels of social interaction: the individual as a social actor; the individual's family or kin group as a site of collective privacy; the local public space in which that privacy is defended by the individual in question; and the larger and unspecified audience that - especially now in the YouTube age - has effectively ruptured the possibility of containment for good (but not necessarily for the better!). This seems a much more useful way of looking at the old honor and shame issue as well; reputation, as a public matter, is all about moral economy and - what is especially relevant to the present discussion - moral architectonics.

The term "moral architectonics" needs some further explanation, and I propose to do this by example. In Greece today the old Ottoman wooden window-boxes (kioskia) have often lost their distinctive lattice-work window coverings, but older people recalled, at least until recently, that this served as the architectural equivalent of the veil: it allowed women to observe the street without themselves being observed. Confined as they were to the domestic sphere, they could thus acquire knowledge of events beyond the home, but were not subject to external temptations. Moreover, as the window boxes became Hellenized, they also lost that peculiar feature, while still expressing the ideal of separating the domestic sphere from the dangers of the street. Here we begin to see more clearly, I suggest, what might be gained by characterizing architecture as the clothing of the body politic. 


\section{Structures and levels: The condensation of concentricity}

Architecture also has the effect of condensing concentric levels of identity. It fuses the four levels I have mentioned here, drawing on their relationship of metonymy-synecdoche to suggest that the home is not only the architectural expression of the family (or other appropriate dwelling unit). For the home is, simultaneously and concomitantly, the expression of an individual's standing as head of family, of a village culture, and of a national culture always under threat from brutish enemies - in Rhodes, during the 1974 Turkish invasion of Cyprus, a common expression was that of a man raping the women of his enemy's house. All these levels are heavily gendered; all draw a clear distinction between what may be revealed and what is to be concealed.

This disaggregation of the levels of privacy in the architectonics of social life gives new life to Simmel's awareness of the social - and therefore conditional - nature of secrecy (Simmel 1964). It allows us not only to expand his insight by examining how secrecy is actually performed, but then to extend that analysis further by applying it to such concepts as "crowding," "privacy," and "gatekeeping." Both socially and architectonically secrecy and privacy, like justice, must be seen to be done; and this paradox demands appropriate public spaces organized to give dramatic weight to the simulacrum of privacy that people wish to enact. It also allows them to attack those against whom they might be able to score some advantage. In this regard, there is not much difference between the moral manipulations that have so often been described by ethnographers of Mediterranean village life and the play of privacy and the right to public space that characterizes the impact of technology on urban social life. As globalization has brought an increasing tendency to expand social relations beyond the face-to-face, however, the social nature of privacy and, inversely, the secretive nature of political transparency become more resistant to identification. There is an increased literalization of such concepts, and this accompanies the literalization of the past, of heritage, and of group culture that we see in such phenomena as the gentrification of "historic districts" in cities.

In these terms, we see that any claim to the achievement of total privacy is, like the claim to pure literality, self-deceiving. If privacy is so total as to be invisible, it has no semiotic force at all; it is the proverbial tree falling in an empty forest. Once privacy registers on public consciousness, on the other hand, it is no longer completely private. Such contamination of its abstract ideal form renders it ineluctably social. Even the growing privatization of public space can only be a social act, and, as such, is always potentially open to contestation. In the sometimes acrimonious 
debates about the "occupation of public space" in Rome, for example (see Cellamare 2006), it becomes clear that privatization itself is a very public matter.

Here I would like to return briefly to the matter of cell phone use. This is suggestive for several reasons, not the least of which is the fact that noise pollution - regardless of the information carried by the noise itself - remains a significant criterion for the demarcation of public from private space. (Indeed, the very term is indicative of its symbolic force [see Douglas 1966].) When telephone conversations were confined to the home, the occasional arrival of an unintended listener was often the cause for considerable discomfort and even anger. Today, however, it almost seems as though those who have the most secret business to perform (and "perform" seems the mot juste here!) are also the most eager to be overheard. Yet what they wish others to overhear, I suggest, is not the content but the external form of their performances. Not so many years have passed since poorer citizens of at least one southern European country carried wooden copies of cell phones in order to impress their unknown but ever-present audience. Today cell phones are commonplace and relatively inexpensive, so that it is the air of importance with which they are used that really counts.

This also has consequences for the analysis of privacy. For while it is usually the aggrieved and involuntary listeners to cell phone conversations who claim an invasion of their own privacy (or at least of their aural space), the speakers, too, can put on a good performance of irritation if others appear to be listening too eagerly — but can also defend their right to the use of public space when these others object. Clearly the boundaries are at least as negotiable in today's cities as they ever were in the villages and tribal societies that used to make up the bulk of anthropologists' stamping grounds. Privacy and secrecy, again, must be performed in order to exist at all: they are socially constituted, and that process requires a socially adroit understanding of the uses of physical space.

This insight did not come from an urban setting at all, but is inspired by the actions of my friends in the Cretan mountain village (see Herzfeld 1985). That village, as should already be evident, has a well-deserved reputation as the home of a swashbuckling crowd of irreverent, rebellious, and frequently lawless shepherds, who also happen to be - as perhaps everyone constantly engaged in tweaking the self-seriousness of a bureaucratic nation-state must be - extraordinarily adept social theorists and semioticians of their own political condition. Among the many striking observations through which I was able to learn from these rare sensibilities were two that illustrate the central point with particular force. 


\section{Performing secrecy: Lessons in the architectonics of concealment and surveillance}

On one occasion I was intending to go to the funeral of an elderly man who had not enjoyed particularly high esteem from his fellow-villagers, but whose wife and two daughters were preparing to keen the often improvised dirges for which Greeks have long been famous (see Herzfeld [1993] for a detailed analysis of the event). Hoping both to record some gems of improvised folk poetry on the one hand, but worried about hurting villagers' feelings on the other, I consulted a close friend. His response was clear and unequivocal: don't take the big reel-to-reel tape recorder, which would be too obtrusive, but use the small cassette recorder - but make sure that it pokes out of your pocket, said he, so that people will realize that you are trying to be discreet. This seemed to me to recognize something more subtle than the concealment that is so much a staple of ethnographic descriptions of the Greek countryside (Campbell 1964: 192; du Boulay 1974: 82; Friedl 1962: 14); it is about the dramatic performance of acts signifying the decorum that concealment supports. In this sense, it is not unlike the logic of discussing ostensibly top-secret business deals and family scandals on a mobile phone; it broadcasts information in a way that redounds to the speaker's credit while possibly airing some dirty linen that will damage the reputations of others.

My second example is in fact one that I witnessed on more than one occasion. The village is notorious, as is the entire area (see also Saulnier 1980; Tsantiropoulos 2004), for endemic, reciprocal animal-theft. I spent four months there without realizing that the occasional hints I heard alluded to anything more than the long-vanished activity of hard times marked by famine and foreign occupation. When I finally discovered that these were commonplace occurrences and key to the men's social standing, I naturally became deeply interested; indeed, it became the central topic of my research. And the first order of business was to try to get some friends to recount their own recollections of raids and counter-raids and all the social business that went on around them.

Somewhat to my bemusement, this did not prove at all difficult. Men who were initially reluctant to tell me about their own activities began to realize, as my animal-thief's technical vocabulary improved, that I knew about the practice itself and that if they failed to tell me about their own engagement in it they risked appearing as relative weaklings in a society where telling a good story is almost as important as the original activity itself - and that in any case there was no longer any point in trying to be secretive with me. But the way they approached my rented house, which was in the very center of the village, was instructive. It was as though the 
most important aspect of these visits was to make sure that everyone knew both that they were my guests and probably telling me some pretty scurrilous stories and that they could perform a highly dramatized image of discretion - casting a conspiratorial eye around before cautiously, very cautiously, mounting the steps to my house, in full view of the road but with one house in between to provide a semblance of cover. Since everyone soon knew that I was interested in hearing stories about animal-theft, it became increasingly clear that the point was not even so much that of trying to seem as though they were protecting the communal reputation. It was much more that of convincing each other that they knew there was something rather naughty about telling tales to a stranger, but that - well, they had been especially tough and inventive thieves, and so who could blame them for wanting to display their talents to the gullible (and probably quite harmless) foreigner?

Such performances not only also appear in the less dramatic guises afforded by urban life but inform the architectonic arrangements of social life. Fashionable pastry shops and rather less fashionable ouzo bars and coffee shops are places to see and be seen, but also to be seen to avoid being seen. While sophisticated urbanites may not engage in the illegal activities of the villagers I have just described, their sexual and aesthetic adventures are to some extent always on view - if, frequently, as provocative shadow-hints of a thoroughly opaque reality. And what are we to say about the careful cultivation of an air of officious importance by ambitious young businesspeople who may in fact not be doing anything very important at all? Yet their elaborate performances of discretion are so loud as to suggest that a sense of importance is in fact the critical goal.

The public-private dichotomy has come under considerable critical scrutiny in recent years, not only because of its seemingly formal binarism, but also because the ideologies of property ownership and the expansion of the public sphere both complicate any simple division of semiotic labor between these two supposedly discrete domains of social life. One wonders: if secrecy can be performed, can privacy also be performed? (I will leave it to dishonest politicians to demonstrate that public concerns can be dissembled to vanishing point.) I suggest that it is here that the separation of social from architectonic analysis is especially pernicious; privacy is necessarily both social and architectonic, and this double embeddedness allows for a good deal of creative play.

In many cultures, of which central Italy and central Thailand are two excellent examples, artisans and merchants often lived above their workplaces. This arrangement not only allowed them to engage family members in economically productive activities, but it also allowed them to exercise a degree of surveillance over the street - a self-policing that 
one can still occasionally encounter, but that, in Italy especially, the new demographics are rapidly rendering obsolete. As (in Italy) rents rise astronomically, and as (in Thailand) the lure of modern housing is not balanced by much new interest in historic dwelling places, these forms of informal social control start to disappear. The few urban enclaves of an older lifestyle in Bangkok are under threat (Herzfeld 2006); in the case of the community I have most closely studied there, that of Pom Mahakan, there has been effective community surveillance that both ended a long history of drug use and sale and now protects the community's children from similar temptations emanating from outside. But a formerly hostile municipal government came close to evicting the entire community partly, and ironically, on the specious grounds that it was riddled with narcotics! More salient to the municipality's erstwhile plans was the fear that a slum community might cause real estate values to depreciate, and it was only a sustained campaign and the astute community leadership's public elaboration of the community's historical importance that saved it from extinction. The point at issue here is that informal surveillance, which operates on a civil basis (consensus, wheedling, and the occasional threat veiled in terms of polite commiseration), can easily yield - and in places less fortunate than Pom Mahakan has yielded - to a vision of planning that quite literally has no space for such informal structures of community maintenance.

It is perhaps no coincidence that sentiment in this particular community favored the construction of row houses rather than stand-alone units. Living in a public space in no way prevents people from having secrets, but it does give them a sense of shared responsibility. Romans recall that even - or perhaps especially - under conditions of dire poverty in the pre-World War II years - most working class residents were fagottari - people who would share their food in simple trattorie that served little more than wine, and in this they were virtually indistinguishable from the wine and oil shops, their function announced in a simple inscription carved in the stonework of the ground floor, at frequent intervals along the street. These were examples of the casa e bottega (literally, "house and shop") arrangement, which thus facilitated not only the maintenance of low-income family businesses but connected them with the social life of the neighborhood. Quarrels (especially between women) were considered a form of high drama and a source of endless entertainment; here there was no privacy - there was only secrecy, and that was easily breached.

In other societies, the architectonics of social space may have exactly the opposite effect, and seem to have been designed deliberately to do so. The latticed window-boxes already mentioned have not entirely disappeared, especially in some of the predominantly Islamic successor 
states. More generally, small private houses can fairly effectively contain a family's most intimate secrets. But such structured isolation may also provoke the desire to rupture it; this kind of privacy is a gauntlet thrown down to the social order. Gossip still feeds off highly sense-oriented clues - the smell of cooking, the condition of clothes, the state of the paintwork on the front door. In the small seaside town where I conducted research on the impact of historic conservation, craftsmen avoided taking on patrikin as their apprentices because of the fear that, if (for example) an artisan punished his brother's son, the whole neighborhood would get to hear of it and the clan would become the object of endless, damaging ridicule (see Herzfeld 2004: 178-186). Small dwelling units thus do not guarantee secrecy; what they offer instead is a way of displaying a family's autonomy and self-sufficiency (especially, but not exclusively, in the sense that a wife could thereby demonstrate that her father had equipped her with an impressive dowry - especially if, as was often the case, the family came from a village where the norm was for the groom's family to supply the house).

Modern architecture restricts such possibilities. Apartments can be bought at a great distance from each other; while it used to be common to see incomplete houses in top of which metal attachments declared the intention of dowering the next daughter as well, buying an already existing apartment is today a more prestigious option. The result is that, as people often lament (although they may actually enjoy the change), they no longer know each other as in a face-to-face society. Now the habits of yesteryear suddenly become pollutants - "matter out of place," in Mary Douglas's (1966) justly celebrated definition of dirt; the official values of the past are reduced to source of embarrassment under conditions of modernity (see Özyürek 2004: 119-122).

Changes of this kind are changes in the forms of physical constraint on the social body. Noises that were once the ordinary sounds of artisanal work become the subject of complaints; they are replaced by the loud night-time chaos of pubs and bars, but this - at least in theory - is strictly regulated. Smell, too, becomes a noisome intrusion (Classen 1993: 81-83); it is no longer a source of information but a nuisance. The street has ceased to be a social theater and a theater of the senses; it has instead become a functional unit in a modernist project in which even historic status becomes an exemplification of bureaucratic modernity (see Scott 1998: 120-125).

Nonetheless, distinctive local patterns of interaction continue to suffuse the ways in which space is used. Notions of privacy, secrecy, and performance are embedded in millennia of social experience, and they will not simply go away. Indeed, they generate entirely different responses than 
we would expect on the basis of a political value system that today claims global status. If, for example, it is acceptable for a person to lie in defense of family interests, we should expect people to organize domestic architecture to conceal family secrets. It will be reflected in the structure of workplaces such as those where - as happens in many parts of the worldapprentices are expected to "steal with their eyes" rather than to receive verbal instruction. Here again we see that things are not what they seem - are seen - to be. The apparent reluctance of master craftsmen to reveal trade secrets to their apprentices may stem for a fear of competition from the rising generation, and indeed there is extensive evidence that this is the case (e.g., Angioni 1989; Herzfeld 2004: 50; Maher 1987; Singleton 1989). That said, however, the fervent denial that the toughening process involved here also prepares the more adept for the agonistic arenas of male craft production masks a training in deception that is itself a performance of secrecy. When the old workspace of saddlers, carpenters, and ironworkers gives way to the ruthlessly linear production line of the shop floor, there is nothing left to be secretive about: the worker does not have the personal investment of the lone artisan, and the techniques are prefabricated so that they can be used throughout the profession.

\section{Neoliberalism ineluctable?}

Such deskilling also has appalling human costs (see Blum 2000). It destroys the individual basis of craft mastery, reducing skilled workers to cogs in a machine. In the process, it also shifts the management of secrecy away from an individual game, albeit one with clearly defined social rules, and toward the protection of class interests. Both in terms of the removal of ordinary work from the offended eyes of the wealthy - a move that is not unlike the removal of tanneries and abattoirs from city centers in an earlier age (see Vialles 1987) - and in terms of the devaluation of the work itself, zoning of this kind often contributes to a hardening of social stratification. This is especially true in cities like Rome, where until recently people of different classes lived in a relatively harmonious social patchwork, and where the most recent evictions have often targeted properties the residents of which have seemed especially representative of the old order.

Complaints about noise and smell, however, are not only about the actual spaces of residence. They are also about the larger arena in which public communication took place. In many small southern European towns, for example, neighbors would assess each other's economic standing by sniffing the air to determine what they were cooking (see Herzfeld 
1991: 89). The sound of artisanal labor could even convey half-humorous messages, as when cobblers' hammers changed rhythm to announce the passage of a beautiful woman (Herzfeld 2004: 59). These smells and sounds, however, also announced a mingling of work and residence that, while representative of life in poorer quarters, arguably offended against the ideal order of the emergent world of the gentrifiers and thus, spatially and sensually, violated the terms of their system of classification. Yet we should be in no doubt that classification, rather than literal nuisance value, is the issue at stake. Those same people who object loudly to the sound of a carpenter's machinery think nothing of the racket from a pub whose often inebriated customers spill out onto the sidewalk until the small hours of the morning.

Such privatization of public space - a new "tragedy of the commons" - extends the purchased entitlement to a home far beyond its walls, and generally accompanies or parallels gentrification (see, e.g., Smith 2006). The logical end of this literal process of enclosure is the gated community (Low 2003). Yet it is not clear that such collective self-enclosure actually obviates the need for smaller units to protect their interests. For just as architecture clothes the collective body politic, the individual home may conceal acts and conditions that diverge substantially from the collective norms, and the sometimes forbidding similarity of the individual dwelling-units often masks internal dispositions that contravene the ideologically conformist model. Ethnographically, such deviations are largely inaccessible; the difficulty with which an ethnographer enters those secret domains is a clear measure of their success. What has changed is not the secrecy with which family life is conducted - that has become more inviolate than ever - but the degree to which physical conditions and the values that inform them permit or enable such unmasking.

Such communities have perhaps finally succeeded in overcoming the Simmelian paradox. Here there is no public performance of secrecy; there is virtually no public space in which to perform it, because it has all been privatized - or rendered so public that the only performances possible, such as the drunken conversations outside the pubs at night, have become performances of openness and transparency. (This does not mean that they are either open or transparent; indeed, like the transparency of politicians already mentioned, or like the ersatz friendliness of the flight attendant or waitperson, they can serve the interests of concealment behind a mask that simulates sociability in order to keep it at bay.) Such questions await further, and difficult, ethnographic investigation.

When people live together in a social environment that admits of considerable interaction, by contrast, the performative privacy of home rep- 
resents only the first step in a long historical process of the solidification of such denials of privacy. It has long been a commonplace of anthropological writing about southern Europe, for example, that what matters is less what people do than what they are rumored to do (e.g., on Greece alone, see Campbell 1964; du Boulay 1974; Friedl 1962). This alone shows that secrecy cannot exist in a vacuum; it is a relative measure of success in the husbanding of social capital, not an absolute value in and of itself.

Domestic architecture often reflects this agonistic dimension of social life. At a very early stage in the development of the ethnography of Greece, for example, Ernestine Friedl (1962: 13) famously pointed to the way in which Greek villagers constructed their houses - "either by inadvertence or by design" (Friedl 1962: 14) - so as to protect the interior spaces from the prying eyes of neighbors. Note that such design features, which defy modernist planners' notions of order, require a more or less general agreement that they are socially appropriate and normal; otherwise they would backfire and be treated as evidence of anti-social attitudes. But here we see that the idea that Greeks (and other southern Europeans) traditionally lacked any notion of privacy founders, not only on the linguistic determinism noted above, but also on two further errors of judgment: first, the literal-minded assumption that privacy is not a public matter; and second, the clear evidence of a convention permitting and even encouraging concealment of the zones of familial intimacy - an aspect that is lost, ironically, as people move from "traditional" dwelling spaces to apartment blocks or gentrified urban houses.

Such moves deprive householders of the ability to impose the constraints of privacy on their dwellings. The far from uncommon New England convention of banning fences between gardens would astonish most Greek town-dwellers as much as it clearly disconcerts Californians more focused on ideals of privacy as a form of visible boundary maintenance (see Perin 1988: 34; see also Perin 1977: 105-106). ${ }^{7}$ It is, however, a sign of relative prosperity; the houses are large enough and constructed in such a way as to protect privacy. When citizens have less control over the houses themselves, the concomitant loss of privacy becomes a major concern. It informs the fury of the residents of towns and cities who discover that now their homes are subject to control by the historic conservation authorities; it also informs the powerful sense of frustration experienced by many who move from rural houses to large, impersonal apartment blocks. And while stances of resistance are common - Greek Cypriots' introduction of colorful house exteriors in a staid British city neighborhood is a revealing example because it also places such resistance in its cultural-political context (Thompson 1979: 50) - they do little to delay 
or affect the process. As a result, performances of privacy are now forced onto the street.

\section{Law, privacy, and space}

It is interesting, in this connection, to recall that the president of the Italian privacy authority traces an important part of the current legislation to architectural concerns (Rodotà 2005: 36). He recalls that an early indication of the problem was that in a certain, relatively new workingclass suburb (Tor Bella Monaca), the greatest complaint was that one could not even take a shower or make love to one's spouse without the neighbors observing every detail. These houses had been designed without concerns of privacy in mind, and followed utilitarian models that took no account of traditional modalities; moreover, the desire for surveillance had already, in the Fascist era, produced a mode of structuring such complexes so that passage through the few exits and entrances could be carefully controlled and recorded. The infamous "Serpentone" at Corviale, although built in the 1980s, followed the high-modernist idiom of Le Corbusier, with its deliberate inattention to individual and family needs and its emphasis on rational planning. None of these structures allowed for what had been considered a reasonable expectation of living conditions even in the most squalid of the older buildings either in the inner city or in the rural hinterland.

What is especially interesting for our purposes is that these complaints emerged clearly and strongly long before the office for the protection of privacy was created. As Rodotà (2005: 34) recalls, people initially understood privacy as a right to a decent "private life" (vita privata), a term that could even - as in the incident that he relates - simply mean the right of a daughter not to suffer at the hands of her villainous husband! Rodotà wisely chose not to laugh at this incident, but to see it as the expression of a larger concern in which issues of personal dignity could be understood as the key. ${ }^{8}$

Even more significant, moreover, is the way in which Rodotà uses, apparently in easy alternation with la privacy, the concept of riservatezza a term that implies the clearly demarcated spatiality of privacy, that has clearly been in use for much longer than its English-derived equivalent, and that also conjures up echoes of confinement - as in the American concept of the "reserve" (riserva in Italian), a place for confining native populations. 9 The notion of riservatezza, which is also used of "reserve" in the sense of not giving too many of one's thoughts away to others, is not a precise equivalent of "privacy," which appears to have entered Ital- 
ian usage largely under the influence of United States jurisprudence. But it offers a clear indication of a link to older social modalities that may have been obscured by the fallacy of misplaced concreteness that, as I noted earlier, led many observers to mistake the apparent absence of a word for "privacy" for the absence of something like the concept itself.

Rather than seeing the arrival of comprehensive privacy legislation as a triumph of new civic values, therefore, I am more inclined to see it as a restoration of values and practices undermined by new building codes, conditions of life, and oppressive state practices. Rather than an invention or an unfamiliar import, it is a recuperation of values that have been threatened by the modernity it is often - and wrongly — taken to represent. It recalls an essential parallel among the domestic, the local, and the national: the creation of physical as well as conceptual barriers designed to protect intimacies both personal and collective.

Indeed, the deep concern that many nation-states exhibit with regard to their more disreputable cultural habits ${ }^{10}$ — what I have termed "cultural intimacy" - often reproduces patterns of concealment and embarrassment that are very familiar from some of the older ethnographies. In southern Europe, for example, the almost obsessive attention long paid to questions of "honor and shame" could productively be recast as a discussion of modes of the concealment and sharing of such guilty knowledge, a move that would then also allow us to restore a link between the rural societies of two or three decades ago with the urban realities of today - a link that too many ethnographers have simply ignored as irrelevant to their own, no less high-modernist concerns.

Rodotà (2005: 28-29) argues that union-inspired pressure for workers' rights, and especially the legislation that denied an employer access to information on personal attitudes (religion, political affiliation, sexual practices), in effect made it possible to act according to those attitudes with total and, above all, public freedom. Privacy at one level became the guarantee of public liberties at another; employers could observe anything they wanted in the public arena, but they could not use that information because the wider context made discrimination itself an actionable offense.

This seeming paradox, a revisiting in architectural terms of Simmel's original insight, has intriguing consequences for rethinking the implications of urban domestic space, and especially for the human rights aspects of architecture (on which see now Bristol 2006). Housing "solutions" that often provide a quick and unsatisfactory fix for the disruptions occasioned by eviction expose to public view dimensions of intimacy that are regarded as the domain of riservatezza, of privacy. In this regard, they deprive citizens of the right, not only to take a shower or make love away 
from the curious and oppressive gaze of others, but also to engage in acts that violate existing laws, social norms, and canons of propriety. They remove, in other words, the very basis of intimacy - which, I would argue, is an agreement to share and perhaps even enjoy forms of knowledge that are known to be disapproved on the outside. The people of Pom Mahakan, to revert for a moment to a very different setting, did not deny that drug users and pushers had formerly inhabited the community; they argued that it was their ability to police themselves, however, that had made it possible to expel such undesirable elements, and that the very visible presence of a healthy and cheerful adolescent population served as the best evidence of their success: private triumph on public display.

The parallel with the encompassing nation-state is clear. For the state depends on the perpetuation of the specific cultural traits that it most fervently denies to outsiders (Herzfeld 2005). When a state succeeds in removing all such embarrassments, it also removes the very basis of sociality, and so deprives itself of its citizens' pragmatic (as opposed to ideological) loyalty (see also Boyer 2000). I am not arguing in favor of the right to disobey the law. I am arguing, however, that the destruction of privacy removes from the individual citizen the responsibility for making independent decisions as to whether to obey or not, whether to conform or not, and also destroys the possibility of the minor illegality that sometimes makes life livable. This, in turn, makes the state an uninhabitable space, rather like the modernist dwelling that does not allow its residents the comparable degree of freedom of action and decision-making that a modicum of riservatezza would assure them.

The state as a modernist project has had to compromise with the local worlds out of which it has been built, if only because these constitute the moral context of the vast majority of its citizens. In most countries, bureaucrats themselves have emerged from a cultural background not greatly, and sometimes not at all, different from that of other citizens. This realization means that we can no longer perpetuate the myth of a rational modernity totally divorced from its social underpinnings (as Tambiah [1990] has already cogently argued).

It also, concomitantly, necessitates some new contemplation of the "traditional" ethnographic scene - traditional in the double sense of representing an older mode of anthropological writing while also portraying a rural life that is now largely lost (and was perhaps never as isolated or isolating as some anthropologists appeared to believe). It is clearly an absurdity to say that privacy did not exist in those older settings, even if scholars failed to recognize it as such. Rodotà's recognition that in modern Italy the achievement of laws protecting privacy actually allowed for a great deal more public display of one's actions corresponds to a con- 
verse condition in those settings: that the public display of adhesion to prevailing norms and morals actually allowed for greater privacy and freedom of action - because, as her village friends famously told Juliet du Boulay (1974: 82), "God wants things covered up."

The state, however, might disagree - and this is why an ombudsman becomes useful; government can sometimes pry too deeply into matters that are considered private and beyond its legitimate authority. Regulating such matters has become extremely complex. The ongoing battle to restore a human scale to large cities - a struggle that has a long and distinguished history in two of the countries about which I have principally written here (see, e.g., Berdini 2000; Doxiadis 1974) - entails a recognition that privacy is not only an ego-centered legal entitlement but also a highly public good, structured both by the physical fabric of the built environment and by the moral dispositions whereby citizens judge that fabric. When the protection of privacy fails, the results are often catastrophic, especially for weaker segments of the population (see, e.g., Desjarlais 1997).

State interventions in the urban fabric that ignore such key issues inevitably do little more than accumulate problems for the future. Because cultures are complex and multi-stranded, perfectly admirable goals notably historic conservation and a concern with the quality of life may come into protracted conflict with each other. In Greece, for example, the classic case is the use of houses in dowering daughters; it clashed with the requirements of historic conservation in ways that sometimes made expansion impossible or illegal (see Herzfeld 1991: 138-147). Building a dower-house to protect the private life of a daughter is also a highly public affirmation of paternal authority - conceivably even more so since the abolition of dowry as a legal category (see Skouteri-Didaskalou 1991). The reputation of a household head hangs in the balance; and while such patriarchal models may soon become the embarrassing side of national culture (for a Turkish example, see Özyürek 2004), new public ways of demonstrating adherence to the protection of domestic space are already emerging - and often take on, as in Italy, the legal lineaments of the right to privacy.

In this essay, I have not simply sought to demonstrate that plus ça change plus c'est la même chose, although clearly such an interpretation, while superficial, has an element of truth to it as well. My point is a rather different one: that, by paying closer attention to the spatial organization of the moral lives of citizens, of what Kleinman (2006: 219) calls "local moral worlds," we can resist the false (and self-congratulatory) allure of the high-modernist creed according to which we now live in a world freed from the social pressures associated with codes of honor and shame and 
with gossip and rumor. While its idioms are subject to constant reformulation, privacy itself remains firmly public. The view that it is a modern, Western, urban invention springs from a persistent strain of Victorian evolutionism in much civic ideology worldwide, rather than from any actual rupture in the global social order.

This is not to deny that the massive exodus from the countryside into the world's swelling cities has an enormous effect on the ways in which privacy is managed. Indeed, as the construction of dwelling places passes from the often collective efforts of villagers following a familiar pattern to the highly individualistic schemes of planners, architects, and other specialists, a silent public debate about who has the right to privacy is enacted in the very forms of the emergent urban landscape. It does not take a particularly refined semiotics to demonstrate that such constructions not only reflect but also engender new realizations of inequality. But such an analysis must start from the premise that privacy is very much a public matter. It is performed; it is debated; and it is selectively applied. Urban landscapes are palimpsests of its multiple, often mutually contradictory impacts. The old binarism of public and private, like that of structure and agency, must now cede the ground of theoretical elaboration to a dissection of the ways in which that polar opposition itself becomes an ideological instrument in both constructing and resisting the new tragedy of the commons.

\section{Notes}

1. Yet it is important not to over-react. Evans-Pritchard's (1940: 13) infamous crack about "Nuerosis" should be read as possibly a sympathetic irritation, given his evident discomfort with the colonial administration with which he was obliged to work; Barley (1983: 55) has remarked that the Dowayo attributed "Westerners' obsession with privacy" to a need to conceal their habit of taking off their white skins at night — an observation that demonstrates a real appreciation of privacy as an aspect of social life. The colonial narrative style dies hard, yet it often preserves such moments of real insight that suggest a closer affinity between ethnographers' and informants' cultures than the ethnographers, at least, were prepared to concede.

2. One might wish to argue that this was in part the result of a desire to demonstrate, as Davis (1977: 7) has argued, that scholars working in this area are as intrepid as those working further from the European core. But it that is true, it is a further demonstration of the persistence of colonial attitudes toward cultures that are not technically former colonies - a phenomenon that has ramifications far beyond Mediterranean Europe (see Herzfeld 2002).

3. In fact it did. See my ethnographic documentary, Monti Moments (Herzfeld 2007), in which such an encounter briefly appears.

4. I offered to erase this individual's identifiable presence from all segments, and, as one might say, honor was satisfied. The fact that this resolved the dispute and that the 
offended party was evidently completely satisfied does suggest that the desire to avoid a potential public embarrassment was certainly part of the motive behind the objections, but there is also the sense of a victory won - so in the final analysis any interpretation of this scene must acknowledge some considerable degree of indeterminacy.

5. For a comparable instance in the politics of Thailand under then prime minister Thaksin Shinawatr, see Morris (2004).

6. See Buchowski (1996) for an early, if rather different, appreciation of this distinction.

7. See also Perin (1977: 105-106), on "spite fences"; her persuasive speciulation that suburbanites "are accustomed to using walls but not rules" suggests that the desire for privacy is not necessarily a result of crowding but is instead the consequence of a more generally exclusionary proclivity.

8. To be sure, such concerns sometimes spill over into the absurd, as when a court decided that, while it was acceptable (if rude) to call someone by some utterly salacious or scatological epithet, one could not describe that person as a "nobody," since such an insult would deprive the victim of standing as a full person (Il Messaggero, 9 July 2004, pp. 1, 18). But this example, too, shows how deeply the modern modalities of legislative and urban morality are embedded in much older concepts of personal autonomy (see also, for Greece, a particularly relevant discussion in Faubion [1993: 162]).

9. The metaphor of the "Indian reserve" is quite often used as a basis of protest by Italian urban dwellers who feel they have been marginalized and are under threat of being exiled to some unpleasant and over-controlled suburb.

10. I will not address here the question of who decides what is disreputable. Elsewhere, I have argued that this is a consequence of the cultural inequalities left in the wake of European colonial adventurism and its aftermath (see Herzfeld 2004, 2005).

\section{References}

Angioni, Giulio. 1989. Rubar cogli occhi: Fare, imparare e saper fare nelle tecnologie tradizionali. In Giorgio Cardona (ed.), La Trasmissione del sapere: Aspetti linguistici e antropologici, 7-16. Rome: Bagatto Libri.

Barley, Nigel. 1983. The innocent anthropologist: Notes from a mud hut. London: British Museum.

Belmonte, Thomas. 1979. The broken fountain. New York: Columbia University Press.

Berdini, Paolo. 2000. Il Giubileo senza Città: L'urbanistica romana negli anni del liberismo. Rome: Riuniti.

Blum, Joseph A. 2000. Degradation without deskilling: Twenty-five years in the San Francisco shipyards. In Michael Burawoy (ed.), Global ethnography: Forces, connections, and imaginations in a postmodern world, 106-136. Berkeley: University of California Press.

Boyer, Dominic. 2000. On the sedimentation and accreditation of social knowledges of difference: Mass media, journalism, and the representation of East/West alterities in unified Germany. Cultural Anthropology 15. 459-491.

Bristol, Graeme. 2006. Pom Mahakan: Community design and human rights. http://www. claimingpublicspace.net $/$ modules.php?name $=$ News\&file $=$ article $\&$ sid $=6$ ( 9 January 2009$)$.

Buchowski, Michał. 1996. The shifting meanings of civil and civic society in Poland. In Chris Hann \& Elizabeth Dunn (eds.), Civil society: Challenging Western models, 79-98. London: Routledge.

Caftanzoglou, Roxane. 2000. The sacred rock and the profane settlement: Place, memory, and identity under the Acropolis. Journal of Oral History 28. 43-51. 
Campbell, J. K. 1964. Honor, family, and patronage: A study of institutions and moral values in a Greek mountain community. Oxford: Clarendon Press.

Cellamare, Carlo. 2006. Un progetto costruito insieme: Introduzione all'esperienza del Laboratorio. In RomaCentro: dal laboratorio alla "Casa della Città," 13-18. Rome: Palombi Editori.

Chagnon, Napoleon A. 1983. Yanomamö: The fierce people, 3rd edn. New York: Holt, Rinehart, and Winston.

Classen, Constance. 1993. Worlds of sense: Exploring the senses in history and across cultures. London: Routledge.

Collier, Jane Fishburne. 1997. From duty to desire: Remaking families in a Spanish village. Princeton: Princeton University Press.

Cowan, Jane K. 1990. Dance and the body politic in northern Greece. Princeton: Princeton University Press.

Davis, John. 1977. People of the Mediterranean: An essay in comparative social anthropology. London: Routledge \& Kegan Paul.

Desjarlais, Robert R. 1997. Shelter blues: Sanity and selfhood among the homeless. Philadelphia: University of Pennsylvania Press.

Douglas, Mary. 1966. Purity and danger: An analysis of concepts of pollution and taboo. London: Routledge \& Kegan Paul.

Doxiadis, Constantine A. 1974. Anthropopolis: A city for human development. New York: Norton.

du Boulay, Juliet. 1974. Portrait of a Greek mountain village. Oxford: Clarendon Press.

Evans-Pritchard, E. E. 1940. The Nuer: A description of the modes of livelihood and political institutions of a Nilotic people. Oxford: Clarendon Press.

Faubion, James D. 1993. Modern Greek lessons: A primer in historical constructivism. Princeton: Princeton University Press.

Friedl, Ernestine. 1962. Vasilika: A village in modern Greece. New York: Holt, Rinehart and Winston.

Friedl, Ernestine. 1964. Lagging emulation in post-peasant society. American Anthropologist 56. 569-585.

Faubion, James D. 1993. Modern Greek lessons: A primer in historical constructivism. Princeton: Princeton University Press.

Giddens, Anthony. 1984. The constitution of society: Introduction to the theory of structuration. Berkeley: University of California Press.

Giddens, Anthony. 1991. Modernity and self-identity: Self and society in the late modern age. Cambridge: Polity.

Handler, Richard. 1985. On dialogue and destructive analysis: Problems in narrating nationalism and ethnicity. Journal of Anthropological Research 41. 171-182.

Herzfeld, Michael. 1985. The poetics of manhood: Contest and identity in a Cretan mountain village. Princeton: Princeton University Press.

Herzfeld, Michael. 1991. A place in history: Social and monumental time in a Cretan town. Princeton: Princeton University Press.

Herzfeld, Michael. 1993. In defiance of destiny: The management of time and gender at a Cretan funeral. American Ethnologist 20. 241-255.

Herzfeld, Michael. 2004. The body impolitic: Artisans and artifice in the global hierarchy of value. Chicago: University of Chicago Press.

Herzfeld, Michael. 2005. Cultural intimacy: Social poetics in the nation-state, 2nd edn. New York: Routledge.

Herzfeld, Michael. 2006. Spatial cleansing: Monumental vacuity and the idea of the West. Journal of Material Culture 11. 127-149. 
Herzfeld, Michael. 2007. Monti moments: Men's memories in the heart of Rome. DVD. Directed and produced by Michael Herzfeld. Berkeley: Berkeley Media LLC.

Kleinman, Arthur. 2006. What really matters: Living a moral life amidst uncertainty and danger. New York: Oxford University Press.

Low, Setha M. 2003. Life, security, and the pursuit of happiness in fortress America. New York: Routledge.

Macpherson, C. B. 1962. The political theory of possessive individualism: Hobbes to Locke. Oxford: Clarendon Press.

Maher, Vanessa. 1987. Sewing the seams of society: Dressmakers and seamstresses in Turin between the wars. In Jane Fishburne Collier \& Sylvia Junko Yanagisako (eds.), Gender and kinship: Essays toward a unified analysis, 132-159. Stanford: Stanford University Press.

Malaby, Thomas M. 2003. Gambling life: Dealing in contingency in a Greek city. Urbana: University of Illinois Press.

Morris, Rosalind. 2004. Intimacy and corruption in Thailand's age of transparency. In Andrew Shryock (ed.), Off stage/on display: Intimacy and ethnography in the age of public culture, 225-243. Stanford: Stanford University Press.

Özyürek, Esra. 2004. Wedded to the republic: Public intellectuals and intimacy oriented publics in Turkey. In Andrew Shryock (ed.), Off stage/on display: Intimacy and ethnography in the age of public culture, 101-130. Stanford: Stanford University Press.

Perin, Constance. 1977. Everything in its place: Social order and land use in America. Princeton: Princeton University Press.

Perin, Constance. 1988. Belonging in America: Reading between the lines. Madison: University of Wisconsin Press.

Rodotà, Stefano. 2005. Intervista su Privacy e Libertà, ed. Paolo Conti. Bari: Laterza.

Saulnier, Françoise. 1980. Anoya, un village de montagne crétois (Études et Documents Balkaniques 2). Paris: P. H. Stahl/Laboratoire d'Anthropologie Sociale.

Scott, James C. 1998. Seeing like a state: How certain schemes to improve the human condition have failed. New Haven: Yale University Press.

Simmel, Georg. 1964. The sociology of secrecy and secret societies. In K. H. Wolff (ed.), The sociology of Georg Simmel, 307-376. New York: Free Press.

Silverman, Sydel. 1975. The three bells of civilization: The life of an Italian hill town. New York: Columbia University Press.

Singleton, John. 1989. Japanese folkcraft pottery apprenticeship: Cultural patterns of an educational institution. In Michael W. Coy (ed.), Apprenticeship: From theory to method and back again, 13-30. Albany: State University of New York Press.

Skouteri-Didaskalou, Nora. 1991. Anthropoloyiká ya to yinekio zitima, 2nd edn. Athens: O Politis.

Smith, Neil. 2006. Gentrification generalized: From local anomaly to urban "regeneration" as global urban strategy. In Melissa S. Fisher \& Greg Downey (eds.), Frontiers of capital: Ethnographic reflections on the new economy, 191-208. Durham: Duke University Press.

Strathern, Marilyn (ed.). 2000. Audit cultures: Anthropological studies in accountability, ethics, and the academy. London: Routledge.

Tambiah, Stanley J. 1990. Magic, science, religion, and the scope of rationality. Cambridge: Cambridge University Press.

Thompson, Michael. 1979. Rubbish theory: The creation and destruction of value. Oxford: Oxford University Press.

Tsantiropoulos, Aris. 2004. Vendetta sti singkhroni orini kentriki Kriti [Vendetta in the mountains of modern central Crete]. Athens: Plethron. 


\section{M. Herzfeld}

Vialles, Noélie. 1987. Le sang et la chair: Les abattoirs des pays de l' Adour. Paris: Éditions de la Maison des Sciences de l'Homme.

Michael Herzfeld (b. 1947) is a professor at Harvard University 〈herzfeld@wjh.harvard. edu $\rangle$. His research interests include social poetics, ethnography and nationalism, space and time, southern European and southeast Asian ethnography. His major publications include Portrait of a Greek Imagination: An Ethnographic Biography of Andreas Nenedakis (1997); Anthropology: Theoretical Practice in Culture and Society (2001); The Body Impolitic: Artisans and Artifice in the Global Hierarchy of Value (2004); and Cultural Intimacy: Social Poetics in the Nation-State (second edn., 2005). 